\title{
K.H. Abdullah Syafi'ie: Ulama Produk Lokal Asli Betawi dengan Kiprah Nasional dan Internasional ${ }^{*}$
}

\author{
Oleh: Zubair ${ }^{* *}$
}

\begin{abstract}
Abstrak
Tulisan ini bermaksud mengungkap kiprah K.H. Abdullah Syafi'ie dalam gerakan dakwah dan pendidikan Islam di Jakarta pada masa Orde Lama dan Orde Baru. Dalam mengumpulkan data, penulis memanfaatkan dokumen kepustakaan di samping juga menggunakan metode wawancara dan pengamatan. Pendekatan yang digunakan adalah pendekatan sejarah sosial. Hasil riset menunjukkan bahwa K.H. Abdullah Syafi'ie adalah ulama Betawi yang terdidik di dalam negeri tetapi mampu memberikan kontribusi dakwah dan pendidikan yang bersifat modern. Dalam bidang dakwah, ia memanfaatkan radio siaran untuk menyampaikan ceramahnya sehingga dapat disimak oleh masyarakat Jakarta dan sekitarnya. Melalui siaran radio, ia juga melibatkan diri dalam propaganda anti Komunis di masa Orde Lama dan anti kebijakan pemerintah DKI Jakarta yang merugikan umat Islam pada masa Orde Baru. Dalam bidang pendidikan, ia mendirikan sekolah modern dari tingkat sekolah dasar hingga perguruan tinggi dengan sistem klasikal.
\end{abstract}

Kata kunci: Dakwah, pendidikan, pesantren, ulama, Betawi.

\begin{abstract}
This paper intends to reveal gait K.H. Abdullah Syafi'ie in missionary movement and Islamic education in Jakarta during the Old Order and New Order. In collecting the data, the authors utilize the document library while also using interviews and observations. The approach used is the approach of social history. The results showed that K.H. Betawi cleric Abdullah Syafi'ie was educated in the country but is able to contribute propaganda and education that is modern. In the field of propaganda, he used radio broadcasts to convey his lecture so that it can be listened to by people in Jakarta and surrounding areas. Through radio broadcasts, he is also involved in anti-Communist propaganda in the Old Order and anti Jakarta government policies that harm the Muslims in the New Order. In education, he founded the modern school from primary school level to college with a classical system.
\end{abstract}

Keywords: Preaching, education, schools, teachers, Betawi.

\footnotetext{
${ }^{*}$ )Artikel ini pernah disampaikan pada "Seminar Hasil Penelitian Biografi Ulama Nusantara (Betawi dan Banten)" yang diselenggarakan oleh Pusat Lektur dan Khazanah Keagamaan Balitbang dan Diklat Kementerian Agama RI di Hotel Lord Inn Sirkuit Sentul Bogor, 8-9 Desember 2011.

${ }^{* *}$ Fakultas Adab dan Humaniora UIN Syarif Hidayatullah Jakarta.
} 


\section{A. Pendahuluan}

Menurut Azyumardi Azra, jaringan ulama Nusantara dan Dunia Islam tidak hanya di wilayah yang sekarang dikenal dengan Timur Tengah, tetapi juga mencakup Afrika, Asia Selatan, dan Asia Tengah. Oleh karena itu, Azra berargumentasi bahwa Islam Indonesia sangat kosmopolitan; terkait dengan dinamika dan perkembangan Islam di wilayahwilayah lain Dunia Muslim, sehingga Islam di Indonesia tidak berkembang secara terpisah. Sayangnya, biografi ulama Nusantara secara lengkap masih sangat langka. Salah seorang pioner penulis buku biografi ulama Nusantra adalah Sirajuddin Abbas yang menulis Tabaqāt al-Syāfi'iyyahdan mulai muncul semacam 'kamus biografi ulama' mulai abad ke-17.Genre literatur tarajim (biografi) para ulama Nusantara sangat dibutuhkan. Kebutuhan itu bukan hanya untuk mengetahui biografi ulama tersebut, tetapi juga untuk merekonstruksi sejarah sosial intelektual Islam. ${ }^{1}$

Belakangan ini, kajian tentang ulama dan tokoh di Indonesia telah diakukan oleh berbagai kalangan akademisi dengan pendekatan dan disiplin keilmuan yang beragam. Secara umum, berbagai kajian dan penelitian itu telah membuktikan tingginya peran dan posisi ulama dan tokoh agama dalam perkembangan budaya, dakwah keagamaan, transmisi keilmuan-pendidikan keagamaan, perubahan sosial, dan pertumbuhan lembaga-lembaga keagamaan, dan pembentukan corak pemikiran keagamaan masyarakat sekitar. Bahkan, para ulama dan tokoh agama

${ }^{1}$ Azyumardi Azra, "Pengantar" dalam Rakhmad Zailani Kiki dkk. Genealogi Intelektual Ulama Betawi, (Jakarta: Jakarta Islamic Centre, 2011), h. xiv-xvi. juga dipandang memiliki pengaruh yang signifikan terhadap pembentukan karakter bangsa, perjuangan kemerdekaan, perkembangan politik lokal, dan pengembangan wacana keagamaan di masyarakat. Sedemikian tingginya peran pengaruh agama bagi masyarakat sekitar, sampai-sampai kehidupannya memiliki pengaruh terhadap sosial-budaya, sosialekonomi, sosial-politik, dan sebagainya.

Tentang pentingnya peran ulama dalam pembentukan corak keagamaan, transmisi keilmuan Islam, perkembangan pendidikan keagamaan dan lembaga sosial dan dakwah, tampak dari berbagai buku biografi ulama dan tokoh agama yang ditulis dalam beberapa dekade terakhir ini. Untuk sekadar menyebut beberapa di antaranya adalah: Biografi K.H. Zarkasyi (pendiri pesantren Darussalam, Gontor), K.H. E. Muttaqin (Ketua MUI Jawa Barat), K.H. Ahmad Dahlan (Pendiri Muhammadiyah), Prof. Dr. Hamka (ulama, mufassir, budayawan, sejarahwan), Prof. Dr. Harun Nasution (pembaharu Islam, Rektor IAIN [UIN] Jakarta), K.H. Saifuddin Zuhri (mantan menteri Agama, tokoh NU), dan sederet ulama dan tokoh agama lainnya. Dalam konteks penulisan biografi ulama dan tokoh agama Jakarta, antara lain dapat disebut buku yang ditulis oleh Rakhmad Zailani Kiki dkk. Genealogi Intelektual Ulama Betawi: Melacak Jaringan Ulama Betawi dari Abad ke19 sampai Abad ke-21, (Februari, 2011) dan tulisan Ahmad Fadli HS yang menyusun buku Ulama Betawi: Studi tentang Jaringan Ulama Betawi dan Kontribusinya terhadap Perkembangan Islam Abad ke-19 dan 20 (Mei, 2011). 
Fenomena penulisan dan penerbitan biografi ulama dan tokoh agama secara nasional ini jelas patut disambut gembira. Dengan demikian, sisi kehidupan sang tokoh, pemikiran keagamaan, karya intelektual, dan pelbagai aspek kehidupannya dapat dikenali dan memiliki jejak yang jelas bagi perjalanan sejarah pemikiran dan keagamaan di Indonesia. Sayangnya, tidak semua tokoh agama dan ulama dapat dikenali jejak pemikiran dan pengaruhnya. Celakanya, tidak sedikit ulama dengan pengaruh yang besar bagi pembentukan corak keagamaan masyarakat dan pendidikan Islam karena tidak tersedia tulisan tentangnya-yang tidak lagi dikenali sejarah dan perannya bagi perkembangan keagamaan. Dalam konteks inilah, perlu disusun biografi ulama dan tokoh agama lokal yang dipadang memiliki pengaruh besar bagi pembentukan corak pemikiran keagamaan, memiliki jasa yang tidak kecil terhadap perkembangan lembaga keagamaan dan institusi pendidikan, memiliki karya intelektual yang patut dibanggakan dalam bidang keislaman, serta menjadi tokoh panutan bagi pembentukan watak keulamaan di tingkat lokal dan nasional.

Salah satu ulama yang lokal yang memiliki peran yang signifikan bagi pengembangan dakwah dan pendidikan di Indonesia adalah K.H. Abdullah Syafi'ie. Ulama ini mengalami masa-masa penjajahan Belanda dan Jepang dan tinggal di pusat pergolakan dan perjuangan kemerdekaan di Jakarta. Beliau tidak pernah sekolah di Timur Tengah, bahkan dapat dikatakan tidak pernah keluar dari wilayah Jabodetabek (Jakarta, Bogor, Depok, Tangerang, dan Bekasi) untuk belajar, namun keulamaannya setara dengan ulama- ulama Nusantara di jamannya. Selain itu, beliau dapat disebut sebagai ulama yang berpaham Ahlussunnah Waljama'ah (Nahdlatul Ulama) dalam paham keagamaan tetapi berpikiran Muhammadiyah dari segi pengembangan dakwah dan pendidikan dalam merespons modernisasi. Mengungkap kiprahnya dalam pengembangan dakwah dan pendidikan Islam menjadi penting.

\section{B. Sejarah Hidup}

1. Setting Sosio-Historis dan Keagamaan

Terdapat beberapa versi mengenai awal masuknya Islam di Betawi. Pendapat yang umum dan populer adalah apa yang dikutip oleh Abdul Aziz bahwa Islam masuk di Betawi pada saat Fatahillah (Fadhillah Khan) menyerbu Sunda Kelapa untuk mengusir pendudukan bangsa Portugis pada tanggal 22 Juni $1527 .{ }^{2}$ Menurut catatan Portugis, panglima tentara Demak yang berhasil mengusir mereka dari Kota Bandar Kalapa bernama Faletehan pada tanggal 22 Juni 1527. Ketika itu, Portugis di bawah pimpinan Fransisco de Sa. Dalam Carita Purwaka Caruban Nagari karya Pangeran Arya Cirebon (1720M), nama pemimpin tentara tersebut adalah Fadhillah atau Fadhillah Khan. Setelah berhasil direbut, Sunda Kelapa diganti namanya menjadi Jayakarta. ${ }^{3}$ Nama Fadhillah ini, menurut Uka Tjandrasasmita, lebih dekat dengan nama Fatahillah, sehingga yang dimaksud Faletehan dalam berita Portugis adalah

\footnotetext{
${ }^{2}$ Abdul Aziz, Islam dan Masyarakat Betawi, , h. 41 .

${ }^{3}$ Uka Tjandrasasmita, Arkeologi Islam Nusantara, (Jakarta: KPG, 2009), h. 152
} 
Fadhillah Khan. Hal ini sekaligus mengoreksi pendapat Hoesein Djajadiningrat dalam karyanya Critische Bershouwing van den Sejarah Banten (Diss. 1913) sampai karya "Hari Lahirnya Jayakarta" (1956) yang masih berpendapat bahwa Faletehan (berita Portugis) sama dengan Sunan Gunung Jati atau Syarif Hidayatullah. ${ }^{4}$

Ridwan Saidi, seorang budayawan Betawi, mengemukakan versi lain, yaitu bahwa Islam datang ke Betawi berawal dari kedatangan Syekh Hasanuddin yang kemudian dikenal dengan nama Syekh Quro. Syekh Quro adalah seorang ulama yang datang pada tahun 1409 dari Kamboja. Berawal dari tahun tersebut, Ridwan Saidi membuat fase perkembangan Islam dan sejarah keulamaan Betawi. Sayangnya, Ridwan Saidi tidak menyebut nama Fatahillah, Dato Wan, dan Dato Makhtom pada fase perkembangan Islam Betawi tahun 1522-1650. Ridwan Saidi juga mengatakan bahwa pada fase lanjutan antara tahun 1650-1750 tidak ada rekam jejak ulama Betawi yang tertulis maupun lisan. ${ }^{5}$ Adapun fase-fase tersebut adalah sebagai berikut:

a. Fase awal penyebaran Islam di Betawi dan sekitarnya (14181527). Ulama yang masuk dalam fase ini adalah Syekh Quro, Kean Santang, Pangeran Syarif Lubang Buaya, Pengeran Papak, Dato Tanjung Kait, Kumpi Dato Depok, Dato Tonggara, Dato Ibrahim

\footnotetext{
${ }^{4}$ Uka Tjandrasasmita, Arkeologi Islam Nusantara, h. 141-142.

${ }^{5}$ Rakhmad Zailani Kiki dkk. Genealogi Intelektual Ulama Betawi...,", h. 11-12.
}

Condet, dan Dato Biru Rawa Bangke.

b. Fase penyebaran Islam lanjutan (1522-1650). Pada masa ini terdapat tokoh ulama Fatahillah (Fadhillah Khan), Dato Wan, Dato Makhtum, Pangeran Sugiri Kampung Padri, dan Kong Ja'mirin Kampung Marunda.

c. Fase penyebaran Islam lanjutan kedua (1650-1750). Pada fase ini terdapat nama Abdul Mihid bin Tumenggung Tjakra Jaya dan keturunannya yang berbasis di Masjid Al-Manshur Jembatan Lima, keturunan dari Pangeran Kadilangu, Demak, yang berbasis di Masjid alMakmur, Tanah Abang.

d. Fase perkembangan Islam pertama (1750 sampai awal abad ke-19). Pada fase ini muncul nama Habib Husein Alaidrus Luar Batang, dan Syekh Junaid al-Batawi, Pekojan.

e. Fase perkembangan Islam kedua (dari abad ke-19 hingga sekarang) ${ }^{6}$

Pada fase perkembangan Islam terakhir ini, Abdullah Syafi'ie (1910-1985) mengambil peranan. Abdullah Syafi'ie telah mengalami pengalaman hidup dan banyak peristiwa sejarah yang dilaluinya. Ia berada di Jakarta ketika masa penjajahan Belanda (VOC), Jepang, lalu Belanda kembali lagi, masa kemerdekaan, orde lama, dan orde baru. Ini juga berarti bahwa ia sangat memahami betapa menderitanya hidup di bawah bayang-bayang para penjajah.

\footnotetext{
${ }^{6}$ Rakhmad Zailani Kiki dkk. Genealogi Intelektual Ulama Betawi...., h. 12-13.
} 
Masyarakat pribumi dalam hal ini orang Betawi, selalu mendapatkan perlakuan diksriminatif dari para penjajah. Pada masa VOC saja, dapat dilihat bentuk pelapisan dan perbedaan sosial antara orang Eropa yang mendapatkankehidupan yang mewah di Jakarta, sementara orang pribumi pada umumnya hanya mendiami rumah bambu dan beratap jerami. Mereka pun hanya bekerja sebagai petani, nelayan, serdadu, bahkan menjadi babu.

Sebagai bagian dari masyarakat Betawi, Abdullah Syafi'ie hidup dalam suasana pengembangan Islam dalam bentuk pengajian pada para guru mengaji atau ulama yang berasalah dari keturunan Arab Yaman atau Hadramaut. Tradisi keagamaan ini diteruskan dan diwariskan dari masa ke masa kepada masyarakat Betawi. Masyarakat Betawi memandang bahwa para penjajah itu adalah kafir sehingga segala yang berbau penjajah harus dijauhi, termasuk bersekolah pada lembaga pendidikan yang didirikan oleh Belanda. Orang Betawi ketika itu lebih senang belajar dari satu Muallim kepada Muallim yang lain, dari satu guru kepada guru yang lain.

Jepang datang memasuki Batavia tanggal 5 Maret 1942. Jepang menerapkan ajaran "Seikeirei", yaitu kegiatan membungkukkan badan sebagai penghormatan terhadap matahari. Hal ini sangat ditentang oleh ummat Islam, termasuk Islam di Batavia. Hal ini yang menyebabkan ditangkapnya Kiai Zainal Musrafa dan dibunuh. Ummat Islam Baravia sangat marah sehingga Jepang terpaksa berusaha meraih simpati mereka dengan menghidupkan kembali Majelis Islam Indonesia pada tanggal 13 Juli 1942 kemudian majelis ini berubah nama menjadi Majelis Syuro Muslimin Indonesia (Masyumi) yang kemudian senjutnya menjadi partai politik pada tanggal 7 November 1945.

Pada awal kemerdekaan, perjuangan fisik tidak terlalu banyak dilakukan lagi, tetapi yang paling pokok dan krusial adalah menetapkan dasar dan simbol negara Republik Indonesia yang baru merdeka. Perdebatan mengenai dasar negara ini menjadi hangat. Masyumi sebagai wadah bagi ummat Islam dalam menyuarakan aspirasinya menginginkan Islam sebagai dasar, sementara kelompok lainnya yang diwakili oleh PNI tidak menginginkan Pancasila. Karena perdebatan itu, Soekarno dengan terpaksa membubarkan Masyumi dan menganggapnya sebagai partai terlarang. Selanjutnya, Soekarno membentuk Demokrasi Terpimpin dengan jargon NASAKOM (Nasional, Agamis, dan Komunis). Yang pada akhirnya Partai Komunis Indonesia melakukan percobaan kudeta melalui Gerakan 30September 1965 dan berhasil menumbangkan rezim Soekarno yang selanjutnya digantikan oleh Soeharto.

Di masa Orde Baru, masyarakat Islam yang dipimpin oleh para alim ulama bersama-sama pemerintah bahu membahu memberantas komunisme sampai ke akar-akarnya. Setelah berhasil menumpas komunisme, ummat Islam mencoba menyampaikan aspirasinya kepada pemerintah Soeharto mengenai kesatuan ummat Islam dalam wadah Masyumi serta 
memberlakukan Piagama Jakarta sebagai dasar negara, tetapi ternyata tidak mendapat respons yang baik. Yang ada waktu itu adalah marginalisasi politik Islam dengan menjadikan satu (fusi) partai-partai Islam menjadi Partai Persatuan Pembangunan (PPP), partai-partai nasionalis disatukan dalam wadah Partai Demokrasi Indonesia (PDI), dan partai pemerintah dalam Golongan Karya (Golkar). Selanjutnya, Golkarlah merupakan motor pembangunan nasional.

Dari segi sosial budaya, di masyarakat Betawi telah berkembang tiga jenis institusi pendidikan yang dijadikan tempat untuk mendidik anak-anak mereka, yaitu pondok pesantren, madrasah, dan majelis taklim.

Pondok pesantren merupakan institusi pendidikan tertudi Betawi dibandingkan dengan dua institusi yang lain. Pesantren pertama yang berdiri adalah Pondok Pesantren Syekh Quro. Sebelum kemerdekaan, model pondok pesantren di Betawi bersifat salafi. Pesantren yang terkenal ketika itu adalah yang didirikan dandipimpin oleh K.H. Marzuki, Cipinan Muara. Mayoritan warga Betawi menyekolahkan putra-putrinya di pesantren Guru Marzuki, Cipinan Muara tersebut.Pada saat ini, model pesantren salafi di Betawi sudah tidak ada lagi. Yang mampu bertahan adalah pesantren salafi non pondok, seperti Pesantren al-Ihsan, Cakung Barat yang dipimpin oleh K.H. Hifdzillah.

Madrasah yang pertama kali berdiri di Betawi adalah Madrasah Jam'iyatul Khair yang didirik oleh Ali dan Idrus yang berasal dari keluarga Shahab. Ulama Betawi yang pernah belajar di madrasah ini adalah Dr. Nahrawi Abdussalam alIndunisi. Selanjutnya berdiri pula Madrasah Unwanul Falah yang didirikan oleh Habib Ali al-Habsyi (Habib Ali Kwitang) pada tahun 1911. Murid-murid yang dididik di madrasah ini yang kemudian menjadi ulama terkemuka di Betawi adalah K.H. Abdullah Syafii, K.H. Thohir Rahili, K.H. Jayadi Muhadjir, K.H. Haji Ismailo Pendurenan, K.H. Muhammad Naim Cipete, K.H. Fathullah Harun dan Mu'allim K.H. M. Syafi'i, Cepete, K.H. Muhammad Naim, K.H. Syafi'I Hadzami. Lalu berdiri pula Madrasah al-Ihsaniyah, di Salemba Tagelan, yang salah satu muridnya adalah K.H. Fathullah Harun.

Majelis Taklim merupakan lembaga pendidikan informal yang dikelola oleh masyarakat yang berbasis masjid dan mushala. Menurut Ridwan Saidi dan Alwi Sahab, majelis taklim binaan Habib Ali Kwitang (Habib Ali al-Habsyi) merupakan yang pertama di Betawi dan mulai melakukan kegiatan pada tanggal 20 April 1870. ${ }^{7}$ Setelah Habib Ali Kwitang wafat, majelisnya diteruskan oleh putranya, Habib Muhammad alHabsyi dan cucunya Habib Abdurrahman al-Habsyi. Dari majelis taklim ini, muncul ulamaulama besar Betawi, seperti K.H. Abdullah Syafi'ie (pendiri perguruan Asy-Syafi'iyah) dan K.H. Thohir Rohili (pendiri perguruan Islam Ath-Thahiriyah).

Majelis taklim ini berperan penting dalam melahirkan ulama

\footnotetext{
${ }^{7}$ Disampaikan oleh Ridwan Saidi dan Alwi Sahab pada Seminar Genealogi Intelektual Ulama Betawi, 27 Maret 2007 di JIC.
} 
Zubair Ahmad : K.H. Abdullah Syafi'ie ... 321

Betawi yang mumpuni di bidangnya. Salah seorang ulama yang masuk kategori ini adalah Mu'allim K.H. Syafi'i Hadzami yang sangat ahli di bidang fikih mazhab Syafi'i dan memiliki pengaruh yang sangat luas hingga hari ini. Beliau benar-benar merupakan produk dari majelis taklim yang tidak kurang dari 11 majelis taklim yang didatanginya dalam rangka menuntut ilmu di berbagai bidang ilmu agama. Setelah menjadi ulama, beliau pun mengajar pada tidak kurang dari 30 majelis taklim dan telah mencetak beberapa ulama Betawi terkemuka, antara lain K.H. Saifuddin Amsir, K.H. Maulana Kamal, dan K.H. Abdurrahman Nawi. Mereka pun meneruskan kegiatan pendidikan di berbagai majelis taklim. ${ }^{8}$

Menurut K.H. Saifuddin Amsir, keberhasilan majelis taklim mencetak ulama Betawi disebabkan oleh tiga hal. Pertama, pendidikan informal ini tidak dibatasi oleh waktu seperti sistem sks di perguruan tinggi saat ini; kedua, anak didik memiliki kebebasan waktu dan kesempatan untuk menanyakan dan menyelesaikan pelajaran yang tidak dipahaminya kepada guru; dan ketiga, anak didik langsung dihadapkan kepada kasuskasus yang terjadi di masyarakat. ${ }^{9}$

Sistim pendidikan majelis taklim di Betawi memang memungkinkan mencetak ulama. Hal itu dapat dipahami karena setiap pengajian melakukan kajian terhadap kitab-kitab utama yang jarang dikaji di perguruan tinggi

\footnotetext{
${ }^{8}$ Rakhmad Zailani Kik dkk. Genealogi Intelektual Ulama Betawi...., h. 25.

${ }^{9}$ Rakhmad Zailani Kiki dkk. Genealogi Intelektual Ulama Betawi...., h. 26.
}

secara tuntas. Kitab-kitab yang diajarkan di majelis taklim mencakup kajian tasawuf, fikih, hadis, tafsir, ilmu al-Qur'an dan sejarah. Kitab kategori tasawuf antara lain adalah Syarh Hidāyat alAtqiyā', Syarh al-Hikam, Kifāyat alAtqiyā', Anwāar al-Masālik, dan Tanbīh al-Mughtarrīn. Kitab kategori fikih antara lain $S a b$ `ah Kutub Mufidah, Fath al-Mu īn, Bidāyat al-Mujtahid, Mughni alMuhtāj, Minhāj al-Țālibīn, alMahallī, Fatḥ al-Qarīb, Kifāyat alAkhyār, Fath al-Wahhāb, dan Tuhfat al-Tullāb. Kitab kategori tafsir antara lain Tafsìr Ibn Kasìir, Tafsìr al-Nasafi, dan Tafsìr Jalālain. Kategori kitab hadis antara lain Șahīh al-Bukhārī,Sahīh Muslim, dan Nail al-Auțār. Kategori kitab ulum al-Qur'an adalah al-Itqān $f i$ 'Ulūm al-Qur'ān. Kategori kitab sejarah adalah Tārīkh Muḥammad. ${ }^{10}$

\section{Lahir dan Dibesarkan}

$$
\text { Putri K. H. Abdullah }
$$

Syafi'ie,Tutty Alawiyah AS, menulis tentang figur ayahnya yang lahir dari H. Syafi'ie bin H. Sairan dan Nona binti Sa'ari,seorang pengusaha kelahiran Betawi. Pengusaha grosiran mangga itu tinggal di Kampung Balimatraman, Tebet, Jakarta Selatan. Setiap harinya, H. Syafi'ie bin H. Sairan sang pengusaha mangga itu berpangkalan di Pasar Manggarai dan mendapatkan mangga dari Indramayu dan disalurkan grosiran ke berbagai pasar di sekitar Jakarta, sementara istrinya, Nona binti Sa'ari,membuat kecap untuk diperdagangkan (home industri).

\footnotetext{
${ }^{10}$ Rakhmad Zailani Kiki dkk. Genealogi Intelektual Ulama Betawi...., h. 27-28.
} 
H. Syafi'ie bersama istrinya Nona binti Sa'ari mempunyai tiga orang anak. Pada tanggal 10 Agustus 1910, Abdullah dilahirkan sebagai anak pertama. Abdullah memiliki dua saudara, yaitu Rogayah dan Aminah.Nona binti Sa'ari meninggal pada usia yang relatif masih muda, sehingga suaminya H. Syafi'ie menikahi Siti Chodijah dari Kampung Celilitan. Sayangnya, dari pernikahannya yang kedua itu, H. Syafi'ie tidak dikaruniai seorang anak hingga dipanggil menghadap Allah Swt.

\section{Kehidupan Keluarga}

Pada tahun 1928, Abdullah Syafi'ie menikahi seorang gadis yang bernama Rogayyah binti K.H. Ahmad Muchtar. Siti Rogayyah adalah seorang gadis terpelajar dan pernah berkesempatan menjadi pembaca al-Qur' an di Istana Negara di depan Presiden Soekarno pada tahun 1949. Dari pernikahannya, Abdullah Syafi'ie bersama istrinya memperoleh karunia 5 orang putra, yaitu Muhibbah, Tutty Alawiyah, Abdul Rasyid, Abdul Hakim, dan Ida Farida. Pada tahun 1951, Rogayah meninggal dunia dan padatahun 1958, putra pertamanya, Muhibbah, juga meninggal. Setelah beberapa tahun ditinggal Rogayah istrinya, beliau menikah dengan Salamah atas ijin dari keluarga dan putra-putrinya. Dari pernikahan dengan Salamah, beliau dikarunia 10 orang anak, yaitu: Mohammad Surur, Syarif Abdullah, Mohammad Zaki, Elok Khumaira, Ainul Yaqin, Syafi'ie Abdullah, Nufzatul Tsaniyah, Muhammad, Thuhfah, dan Laila Sakinah.

Dulloh, sapaan akrab untuk Abdullah Syafie, mewarisi bakat dagang ayahnya. Ketika menuntut ilmu di berbagai tempat, dia telah berdagang barang-barang keperluan masyarakat berupa kain dan songkok. Bahkan, setelah aktif di masyarakat, dia dikenal sebagai ulama yang energik. Berbagai kegiatan yang dilakukan, mulai dari memberikan pengajian di beberapa majlis taklim, mendirikan dan mengelola pendidikan agama yang kemudian berkembang secara luas, namun profesi dagangnya beliau lakukan, baik di daerah Jakarta maupun di luar Jakarta. Tampaknya, berdagang menjadi sumber ekonomi keluarga dan penopang dakwahnya. Dari hasil laba perdagangan itulah dijadikan modal untuk mendirikan dan mengembangkan institusi pendidikannya. Namun, yang sangat perlu mendapat apresisasi generasi muda Islam, bahwa betapa pun besar bakat dagangnya Abdullah Syafi'i tidak lupa terus menuntut ilmu pengetahuan agama. ${ }^{11}$

\section{Pengalaman Pendidikan}

Abdullah Syafi'ie di waktu kecil sekolah di Sekolah Rakyat (SR) di Laan Meni Jatinegara selama 2 tahun, namun tidak sampai tamat. Selebihnya, ayahnya membawanya ke rumah guru-guru yang alim, para habib, dan ulama terkemuka di Jakarta ketika itu.Di antara guru-gurunya adalah Mu'allim al-Musannif bidang ilmu nahwu, ustadz Abdul Madjid dan KH. Ahmad Marzuki bidang ilmu fiqh, dengan KH. Ahmad Marzuki mendalami ilmu tasawuf dan tafsir, juga belajar berpidato ke Habib

\footnotetext{
${ }^{11}$ Hasbi Indra, Pesantren dan Transformasi Sosial: Studi Atas Pemikiran KH. Abdullah Syafi'ie dalam Bidang Pendidikan islam, (Jakarta: Pena Madani, 2003), h. 109.
} 
Alwi al-Hadad yang tinggal di kota Bogor. Kemudian, pada tahun 50-an kepada Habib Salim bin Jindan di Jatinegara menekuni bidang hadis.

Abdullah kecil diberikan sepeda mahal dan pakaian yang sangat necis dan parlente. Ayahnya membayar guru-gurunya bisa lima sampai sepuluh kali lipat dari pembayaran orang lain. ${ }^{12}$ Ketika usianya 17 tahun, Abdullah Syafi'ie memperoleh pemberitahuan untuk belajar di langgar partikelir dan setahun sesudahnya (usia 18 tahun) berhasil membujuk ayahnya agar menjual sapi-sapinya karena kandangnya hendak dijadikan sebagai tempat belajar agama bersama dengan teman-temannya. Tempat itulah yang kemudian dijadikan lokasi untuk mendirikan madrasah pertama yang berdiri pada tahun 1928.

Pada usia 21 tahun, Abdullah Syafi'ie telah memiliki sertifikat pendidik atau beslit dari rachen scahf sebagai pertanda kelayakan menjadi guru. Di madrasah yang telah didirikan, beliau bersama istrinya Rogayah mengajarkan ilmuilmu agama, seperti ilmu tauhid, ilmu fiqih, ilmu akhlak, dan ilmuilmu lainnya.

${ }^{12}$ Tutty Alawiyah, "Mengenal Figur KH. Abdullah Syafi'ie Sebuah Catatan Lintas Sejarah" dalam Tutty Alawiyah, Satu Abad KH. Abdullah Syafi'ie (1910-2010): Kepemimpinan dan Keteladanan $\mathrm{KH}$. Abdullah Syafi'ie, (Jakarta: Universitas Islam As-Syafi'iyah, 2010), h. 2. 


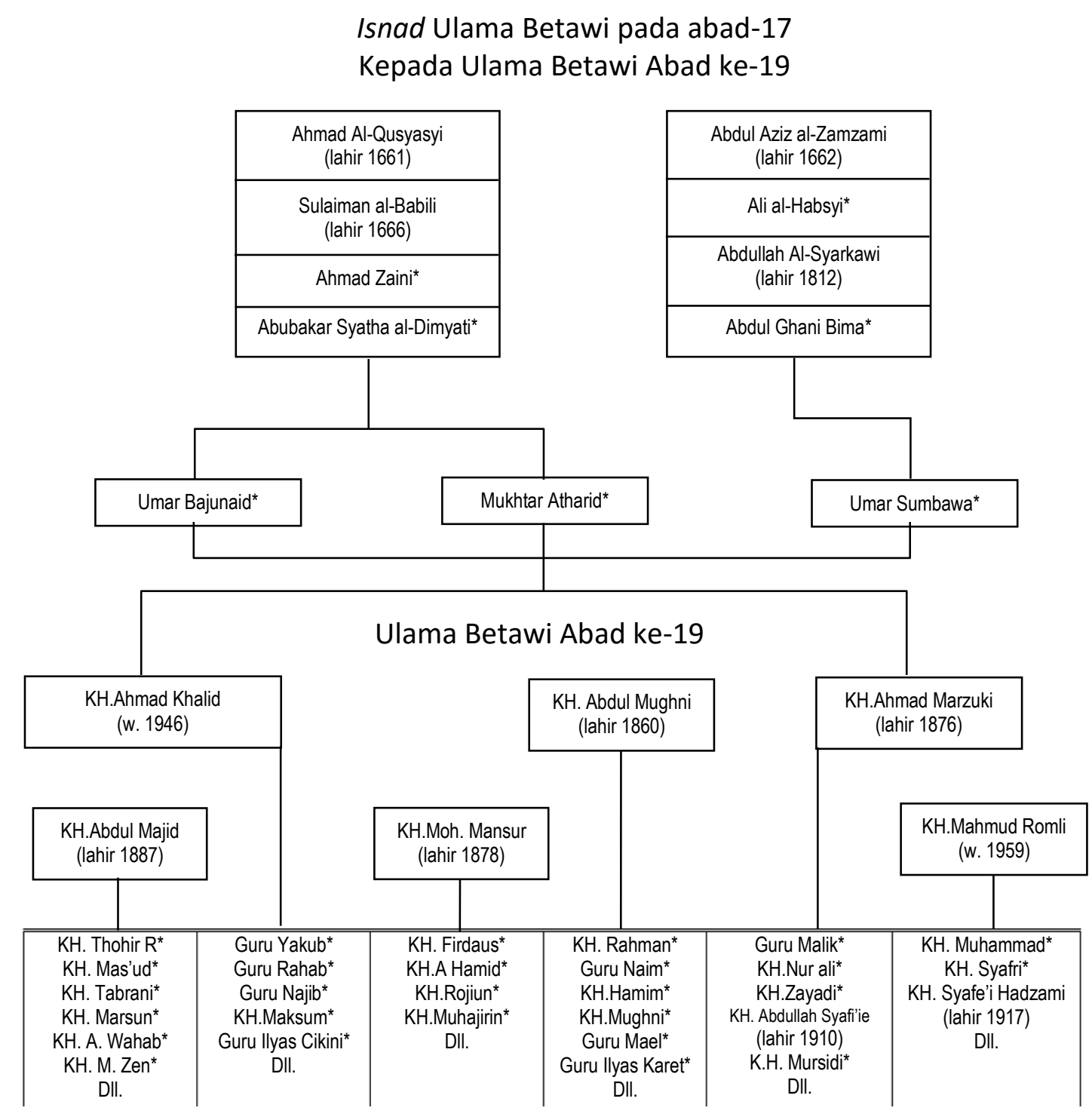

Silsilah yang berdasarkan tahun lahir dan atau wafat yang lebih lengkap dapat dilihat pada skema yang dibuat oleh Ahmad Fadli HS. berikut: 
Zubair Ahmad : K.H. Abdullah Syafi'ie ... 325

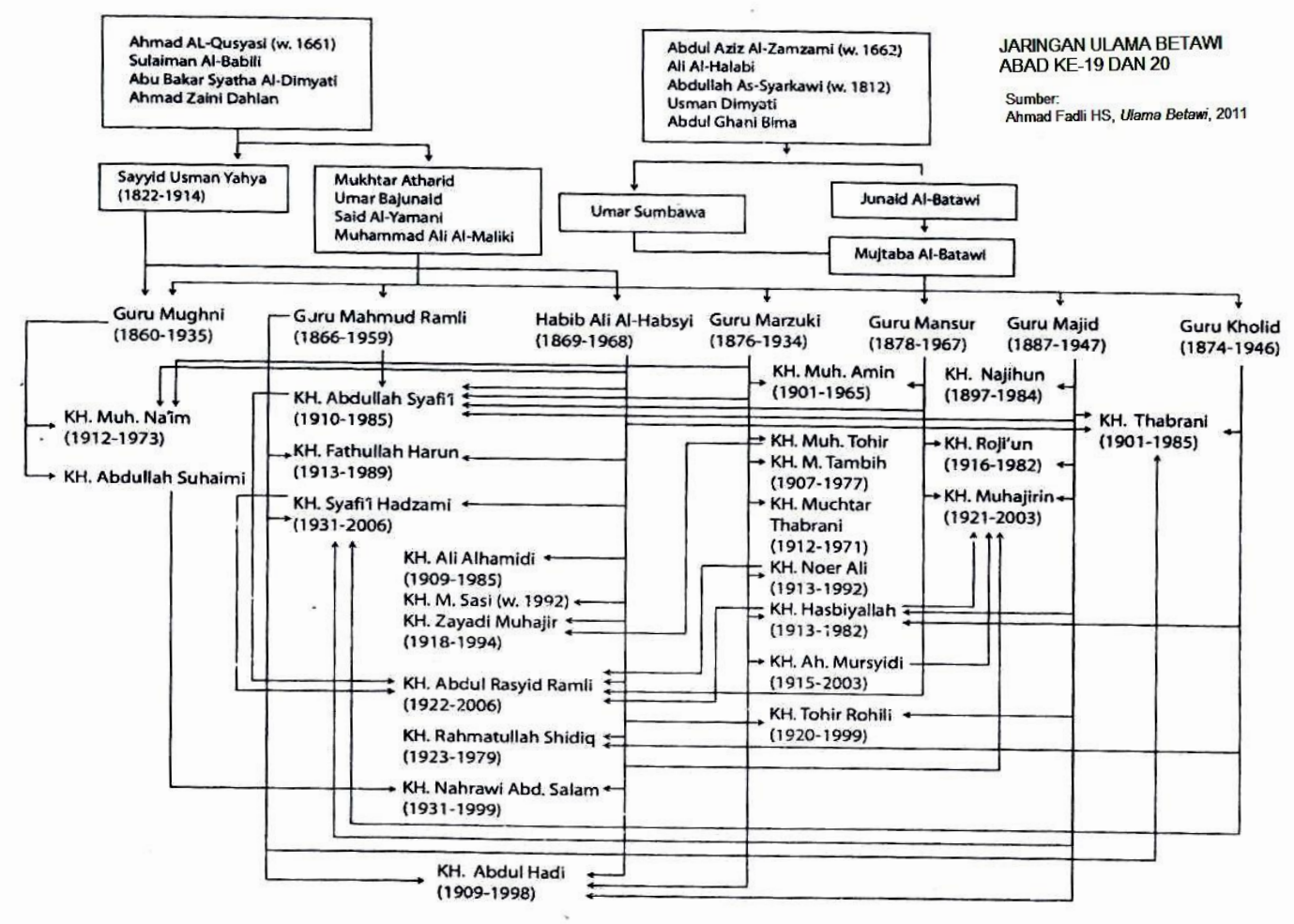

Silsilah ini memeperlihatkan isnad para ulama Betawi kepada tiga ulama (Mukhtar Atharid, Umar Bajunaid dan Umar Sumbawa) dan selanjutnya kepada dua ulama Haramain ternama abad ke-17 (AlQusyasyi dan Al-Zamzami). ${ }^{13}$ Dari beberapa ulama itu telah memproduksi ulama-ulama Betawi yang disegani yaitu K.H. Moh. Mansur (1878-1967), ${ }^{14}$ K.H. Abdul

${ }^{13}$ Lihat Abdul Aziz, Islam dan Masyarakat Betawi, h. 65; dan Ahmad Fadhli HS, Ulama Betawi: Studi tentang Jaringan Ulama Betawi dan Kontribusinya terhadap Perkembangan Islam Abad ke-19 dan 20 (Jakarta: Manhalun Nasyi-in Press, 2011), h. 215-216.

${ }^{14}$ Moh. Mansur, lahir di Kampung Sawah, Jembatan Lima, ayahnya seorang yang alim yang meneruskan kepemimpinan masjid kuno di Kampung Sawah (sekarang bernama al-Mansyuriah) yang didirikan oleh kakek buyutnya yang bernama Abdul Muhit. Kepada ayahnya ia pertama kali berguru belajar agama, dan setelah ayahnya

$\begin{array}{lr}\text { Majid }(1887-1947),{ }^{15} \text { K.H. } & \text { Ahmad } \\ \text { Khalid } \quad(1874-1946),{ }^{16} & \text { K.H }\end{array}$

meninggal ia berguru kepada kakaknya kandungnya, K.H. Mahbub. Ia belajar di Makkah selama 4 tahun dan berguru kepada Syeikh Mukhtar Atharid al-Bogori, Umar Bajunaid al-Hadrami, Ali al-Maliki, Said alYamani dan Umar Sumbawa. Gurunya yang terakhir pernah mengangkatnya sebagai sekretaris pribadi, karena dianggap cakap dan rapih serta tertib tulisannya. Ilmu-ilmu yang dipelajari, ilmu fiqh, qira'at, ushul fiqh, beberapa cabang ilmu bahasa Arab, tafsir, hadits dan ilmu falak; ia dikenal sebagai ahli falak. Abdul Aziz, Islam, h. 56; Ahmad Fadhli HS, Ulama Betawi, h. 107-112; Rakhmad Zailani Kiki dkk., Genealogi Intelektual Ulama Betawi, h. 47-48.

${ }^{15}$ Abdul Majid, lahir di Pekajon tahun 1887, ayahnya bernama K.H. Abdurrahman bin Sulaiman Nur bin Rahmatullah Rahmatullah ini konon masih keturunan Pangeran Diponegoro. Pertama kali ia belajar agama pada ayahnya sendiri. Setelah belajar di Makkah ia berguru ke Mukhtar Atharid, Umar Bajunaid al-Hadrami, Ali Maliki dan Said al-Yamani. Ilmu yang dipelajarinya adalah fiqh, ushul fiqh, tafsir, hadits dan 
Mahmud Romli (1866-1959), ${ }^{17}$

K.H. Ahmad Marzuki (18761934), ${ }^{18}$ dan K.H. Abdul Mughni

bahasa Arab. Ia dikenal alim dalam tashawuf, tafsir, ilmu falak dan bahasa Arab. Di mata murid-muridnya ia $\mathrm{k}$ menunjukkan keluarbiasaan, yang dalam bahasa Arab, disebut Khariqul 'adab. Ia meninggal dan dimakamkan di Pesolo Bosmol.Abdul Aziz, Islam, h. 57; Ahmad Fadhli HS, Ulama Betawi, h. 113-117; Rakhmad Zailani Kiki dkk., Genealogi Intelektual Ulama Betawi, h. 125-130.

${ }^{16}$ Ahmad Khalid, anak orang biasa yang bukan ulama,ia berasal dari Bogor dan menikah dengan orang Gondangdia. Tidak ada catatan guru mengajinya yang paling awal, tetapi ia pernah bermukim di Tanah Suci selama 11 tahun. Guru-gurunya adalah Syaikh Mukhtr Atharid dan Umar Bajunaid. Ia belajar ilmu agama pada umumnya. Ia dikenal di kalangan ulama Betawi sebagai ahli hadits dan tashawuf. Ia terkenal di kalangan muridnya anti merokok dan suara radio. Ia dikubur di Tanah Abang dalam usia 72 tahun.Abdul Aziz, Islam, h. 57; Ahmad Fadhli HS, Ulama Betawi, h. 99-101; Rakhmad Zailani Kiki dkk., Genealogi Intelektual Ulama Betawi, h. 133-134.

${ }^{17}$ Mahmud Romli, lahir daerah Menteng, asal usul yang lain tidak terlalu jelas. Para muridnya dan bahkan anaknya sendiri berprinsip tidak sopan untuk menanyakan hal-hal yang bersifat pribadi kecuali kepada gurunya, kecuali apa yang dituturkan sendiri oleh sang guru tanpa diminta oleh muridnya. Sedikit informasi yang ada bahwa ia pergi ke Makkah bersama orang tua dan tiga saudaranya. Namun, mereka meninggal di sana kecuali Guru Mahmud. Ia kemudian mengembara di sana selama 17 tahun. Ia dikenal sebagai "jagoan" yang tegas. Postur tubuhnya yang besar menunjang keberaniannya berhadapan dengan siapapun. Ia dikenal sebagai ulama tafsir. Ia meninggal sekitar tahun 1959 - dalam usia 93 tahun.Abdul Aziz, Islam, h. 57; Ahmad Fadhli HS, Ulama Betawi, h. 91-93; Rakhmad Zailani Kiki dkk., Genealogi Intelektual Ulama Betawi, h. 138-140.

${ }^{18}$ Ahmad Marzuki, lahir tahun 1876 di Meester Cornelis, ayahnya bernama Ahmad Mirsad, merupakan keturunan keempat dari Sultan Laksana Mayang, salah seorang Pangeran dari kesultanan Melayu Pattani di

\author{
(1860-1935). ${ }^{19}$ Adapun Abdullah \\ Syafi'ie berguru ke Guru Mahmud
}

Muangthai Selatan, meninggal ketika usia Ahmad Marzuki 6 tahun. Melalui ibunya Siti Fatimah, ia diminta belajar agama ke kakeknya Syihabuddin al-Maduri, khatib dan pendiri masjid Rawa Bangke. Ia mendalami al-Qur'an kepada Haji Anwar dan belajar mengkaji kitab ke Sayyid Usman bin Muhamdmad Banashan yang kelak menjadi ayah tirinya. Di usia yang keenam belas tahun ia belajar di Makkah, berguru dengan Syakh Ali al-Maliki, Umar Bajunaid, Umar Sumbawa, Mukhar Atharid, Ahmad Khatib al-Minangkabau, Mahfudz At-Tremasi, Said al-Yamani, Abdul Karim al-Degestani dan yang lainnya dalam ilmu fiqh, ushul fiqh, tafsir, hadits, dan mantiq. Ia juga mendalami tashawuf dan memperoleh ijazah untuk menyebarkan tarekat Al-Alawiyah dari Syaikh Muhammad Umar Syata. Setelah kembali ke tanah air, atas permintaan Usman Banahsan ia mengajar di masjid Rawabangke selama 5 tahun. Di sini ia merintis berdirinya pesantren di tanah miliknya. Santrinya ditaksir sekitar 50 orang. Metode mengajarnya tidak lazim pada waktu itu, ia mengajar sambil berjalan di kebun dan berburu tupai. Santri belajar perkelompok sebanyak 5 orang untuk kitab yang sama. Seseorang dari mereka menjadi juru baca, selesai membaca Ahmad Marzuki m,emberikan penjelasan. Selesai satu kelompok dilanjutkan oleh kelompok yang lain, mengkaji kitab yang lain dengan metode yang sama. Mengajar dengan cara duduk dilakukannya untuk konsumsi masyarakat umum. Meskipun demikian ada pula santrinya yang mengikuti pelajarannya menjadi juru baca. Ia di samping guru agama, juga sibuk berbisnis (antara lain usaha taksi dalam kota dan angkutan bus trayek JakartaKerawang). Abdul Aziz, Islam, h.58; Ahmad Fadhli HS, Ulama Betawi, h. 101-106; Rakhmad Zailani Kiki dkk., Genealogi Intelektual Ulama Betawi, h. 68-73.

${ }^{19}$ Abdul Mughni, lahir pada tahun 1860 di daerah Kuningan. Ia belajar agama pertama kali pada ayahnya, H. Sanusi bin Qais. Ia belajar pula ke H. Jabir dan Sayyid Usman bin Yahya. Dalam usia 16 tahun ia belajar di Makkah ke Syaikh Atharid, Umar Bajunaid, Said al-Yamani, Ali Maliki, Abdul Karim alDagestani, Mahfudz At-tremasi dan Muhammad Umar Syata. Setelah di tanah air, 
Ramli dan Habib Ali al-Habsyi yang keduanya memiliki isnad ke Ahmad Al-Qusyasyi dan juga kepada Guru Marzuki dan Guru Majid yang keduanya memiliki isnad ke Abdul Aziz Al-Zamzami.

Salah satu kebiasaan Abdullah Syafi'ie yang sampai sekarang masih diteruskan oleh putra-putri dan santrinya adalah setiap selesai shalat, memimpin dzikir, seperti membaca tasbih 33 kali, tahmid 33 kali, dan seperti juga pada umumnya ulama Betawi di acara tertentu membaca ratib Hadad. Ratib ini biasanya disebut dengan "wirid Betawi" karena tidak ditemukan pada komunitasetnis lainnya, dan juga selalu dibaca dalam kegiatan keagamaan yang penting seperti pada saat mengantar orang naik haji. ${ }^{20}$

Didorong ajaran Islam yang mewajibkan ummatnya menuntut ilmu hingga akhir inilah akhir hayatnya, Abdullah Syafi'ie menempatkan diri sebagai penuntut ilmu agama yang tekun dan tahan uji serta mengantarkannya menjadi ulama yang tangguh di kemudian hari, yang memang telah tumbuh sejak usia muda dan berlanjut sampai usia tuanya. Yang menarik, selesai mendalami pelajarannya, lalu beliau mendiskusikannya

ia mengajar ilmu fiqh, tauhid, tafsir, hadits dan beberapa cabang ilmu bahasa Arab. Ia dikenal ulama yang kaya harta, sehingga mengurus kekayaannya itu sengaja menyewa pengacara. Lihat Abdul Aziz, Islam, h. 4960; Ahmad Fadhli HS, Ulama Betawi, h. 8690; Rakhmad Zailani Kiki dkk., Genealogi Intelektual Ulama Betawi, h. 109-112.

20 Lihat Abdul Aziz, Islamdan Masyarakat Betawi, h. 107. Bunyi salah satu Ratib Hadad, yakni Bismillah alladzi la yadlurru ma'a ismibi syai'un fi al-ardli wa la fi alsamai wa buwa al-sami al-'amin. dengan saudara-saudaranya atau di lingkungan tetangga rumahnya. Hingga sampai usia tuanya, tradisi menuntut ilmu ini tetap tinggi sebagaimana dikatakan oleh Abdul Hakim: "Dia meluangkan waktunya kurang lebih 4 jam setiap hari untuk membaca kitab, dan di setiap habis membaca kitabnya dibuat intisarinya. ${ }^{21}$ Bahkan, pada menit terakhir dia akan dipanggil Tuhan, dia meminta kepada putra-putrinya agar selalu membaca sebuah kitab, seperti yang diungkapkkan Abdul Rasyid, "Beliau memiliki semangat keilmuan yang tinggi dan semangat membaca yang kuat, bahkan sebelum dipanggil Allah masih sempat mengingatkan sebuah kitab untuk dibaca. ${ }^{22}$

Adapun murid-murid $\mathrm{KH}$. Abdullah Syafi'ie yang menjadi ulama terkemuka antara lain, $\mathrm{KH}$. Saifuddin Amsir, KH. Abdul Rasyid AS (putranya dan kini sebagai pimpinan Pesantren AsSyafi'iyah, Pulo Air, Lido, Sukabumi), Prof. Dr. Hj. Tutty Alawiyah AS (putrinya, pimpinan Yayasan Perguruan Islam asSyafi'iyah), KH. Abdurrahman Nawi (pendiri Perguruan AlAwwabin), KH. Rahmat Abdullah, dan KH. A. Syanwani (Tanah Sereal, Bogor). ${ }^{23}$

\section{Pengalaman Organisasi}

Di tengah kota Jakarta yang kompleks, Abdullah Syafi'ie tumbuh dan berkembang serta berinteraksi dengan penduduk

\footnotetext{
${ }^{21}$ Lihat Hasbi Hasbi, Pesantren dan Transformasi Sosial,.........hal. 111

${ }^{22}$ Hasbi Indra, Pesantren dan Transformasi Sosial, .......hal. 111

${ }^{23}$ Rakhmad Jailani Kiki dkk, Genealogi Intelektual Ulama Betawi, h. 86.
} 
ibukota Jakarta yang beranekaragam. Dia berinteraksi, berkenalan, dan bersosialisasi dengan banyak orang yang bukan saja berasal dari etnis Betawi, tetapi juga berasal dari etnis Ambon, Bali, Jawa, dan Sumatera. Hasil dari interaksi itu, tumbuhlah kesadaran di dalam diri Abdullah untuk berkelompok atau berorganisasi. Dia aktif menjadi anggota partai politik Islam Masyumi, dan bergaul akrab dengan pemimpinnya seperti M. Natsir. Bahkan, dia dapat mengajak M.Natsir untuk bergabung dalam Mudzkarah Ulama yang beliau pimpin, yang biasanya dalam mudzakarah itu para peserta mengkaji agama melalui kitab kuning. Setelah Masyumi membubarkan diri, Abdullah Syafi'ie tidak lagi menjadi anggota partai politik mana pun. Namun, pada tahun 1977, ia mengaktifkan diri di Majelis Ulama Indonesia (MUI), dan ia menjadi Ketua I di MUI Pusat. Pada tahun 1978-1985, ia dipercaya menduduki jabatan puncak sebagai Ketua Umum MUI di DKI Jakarta dan kemudian pada tahun 1982, ia ditunjuk sebagai anggota penasihat MUI Pusat yang diketuai oleh HAMKA. ${ }^{24}$

Abdullah Syafi'ie sebagai ulama, sangat diharapkan sumbangsihnya di organisasi Majelis Ulama Indonesia (MUI). Di organisasi MUI ini, dia menjalin komunikasi yang baik dengan Ali Sadikin sebagai gubernur DKI, dan menjadi mitra pemerintah dalam mendorong adanya modernisasi atau pembangunan di segala sektor

\footnotetext{
${ }^{24}$ Hasbi Indra, Pesantren dan Transfromasi Sosial, ......hal. 115
}

kehidupan masyarakat. Namun, dalam hal-hal tertentu, untuk membentengi moral masyarakat banyak kebijakan pemerintah DKI, dia kritik dan kritik itu ada yang mendapat perhatian, ada pula yang tidak. Misalnya kebijakan pemerintah dalam melokalisasi wanita tuna susila; melegalisasi perjudian dan sebagainya. Begitu pula denga kritiknya terhadap kebijakan yang dilakukan oleh pemerintah pusat yang berkaitan dengan berbagai kepentingan umat Islam.

Dalam hal melokalisasi wanita tuna susila, pemerintah DKI berpandangan vahwa pelacuran hal yang sudah berlangsung lama dalam kehidupan manusia. Upaya untuk membatasi ekses-ekses pelacuran agar tidak menjangkiti masyarakat luas, karena sering dilakukan di sembarang tempat, pemerintah mengajukan konsep "lokalisasi" untuk mengatasinya.

Kebijakan pemerintah itu sangat ditentang oleh Abdullah Syafi'ie dengan MUI-nya. Abdullah Syafi'ie berpandangan bahwa tindakan pemerintah yang telah melegalisasi perbuatan pelacuran sangat bertentangan dengan ajaran Islam. Pelacuran tersebut sangat dilarang agama karena termasuk perbuatan zina. Jangankan melakukan zina, mendekatinya saja tidak dibolehkan oleh agama. Karena itu, Abdullah Syafi'ie menentang keras upaya lokalisasi pelacuran yang dilakukan oleh Pemda DKI, walaupun hal itu masih tetap berlangsung.

Demikian pula yang berkaitan dengan kebijakan melegalisasi perjudian. Pemerintah Daerah Khusus Ibukota Jakarta 
Zubair Ahmad : K.H. Abdullah Syafi'ie ... 329

(DKI) di bawah Gubernur Ali Sadikin telah melegalisasi perjudian. Ali Sadikin dan pemerintahannya memandang bahwa dana yang akan diterima dari hasil perjudian sangat besar dan dapat mendukung percepatan pembangunan kota Jakarta. Pemerintah berpandangan pula bahwa, daripada para penjudi itu berjudi ke negara lain seperti Singapura, lebih baik mereka berjudi di Jakarta serta ikut membangun kotanya.

Abdullah Syafi'ie dan MUI melihat kebijakan itu sangat bertentangan dengan ajaran agama. Perbuatan itu sendiri di dalam agama Islam sebagai perbuatan dosa, karenanya hasil yang diperoleh melalui perjudian otomatis bersifat haram untuk dimakan dan dikonsumsi.

Pada contoh yang lain, terhadap adanya wacana di pemerintahan untuk mengambil jalan yang pragmatis untuk membakar orang yang meninggal dunia. Pemerintah DKI melihat bahwa kota Jakarta sudah sangat ramai dan padat, sementara itu, lahan yang ada sudah sangat terbatas untuk menampung semakin bertambahnya orang yang meninggal dunia. Untuk itu, sebagai jalan keluarnya ada wacana yang berkembang di pemerintahan untuk membakar mayat Abdullah Syafi'ie juga menentang wacana ini. ${ }^{25}$.

\section{Akhir Hayatnya}

\footnotetext{
${ }^{25}$ Dailami Firdaus, "Latar Belakang Pemikiran Dakwah KH. Abdullah Syafi'ie", dalam Tutty Alawiyah AS, KH. Abdullah Syafi'ie ..., h. 14. Hasbi Indra, Pesantren dan Transformasi Sosial, .......hal. 116-117
}

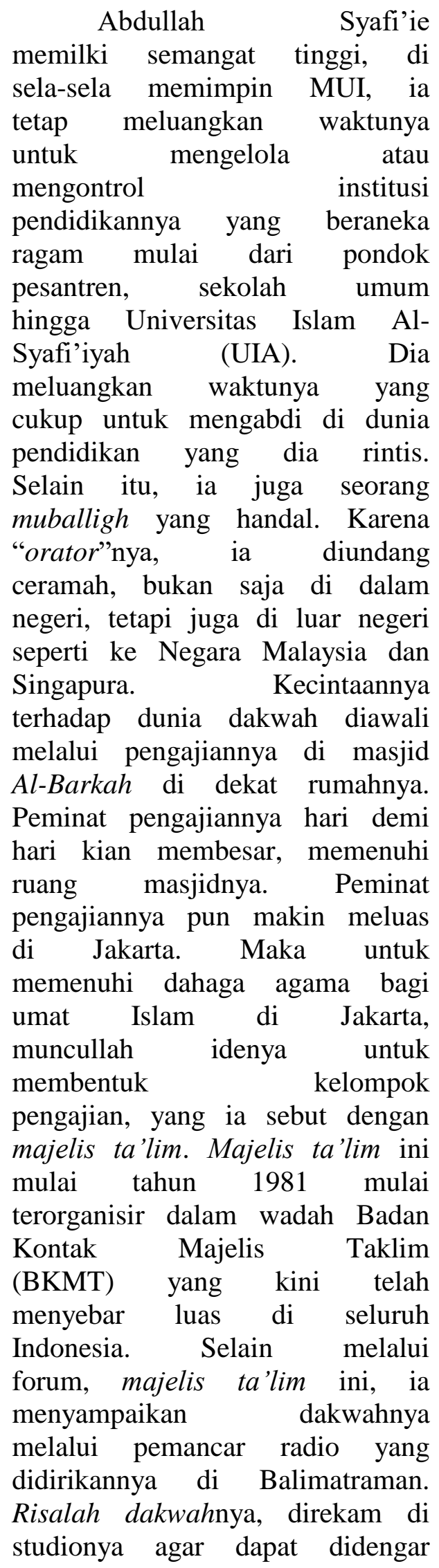


oleh peminatnya di waktu yang lain.

Abdullah Syafi'ie, di saat ia memimpin MUI Jakarta, ia masih meneruskan aktivitas kesehariannya. Perjuangan yang dilakukannya telah banyak dirasakan dan banyak memberi manfaat kepada orang banyak, karena dilakukannya sejak ia masih muda hingga ke usia tuanya. Diusianya yang kurang lebih 75 tahun, fisiknya sudah sangat lemah, dia dirawat di Rumah Sakit Islam, dan tepat pada tanggal 3 september 1985 ia menghembuskan nafas terakhir dan dimakamkan di Jatiwaringin Jakarta. Ia menerima rasa belasungkawa dari Presiden Soeharto, ${ }^{26}$ dan pemimpin MUI pusat mengajak kaum muslimin untuk melakukan shalat gaib. ${ }^{27}$ Lebih kurang 5 surat kabar Nasional dan Warta Berita Antara, dan mengungkapkan sejarah hidupnya. Harian Sinar Harapan memuat judul: "Ulama Besar KH. Abdullah Syafi'ie Meninggal Dunia Selasa Dini Hari"; ${ }^{28}$ Pos Kota Berjudul: "Kita Kehilangan Ulama Besar KH. Abdullah Syafi'ie Tutup Usia", ${ }^{29}$ Suara Karya mengambil judul: "Ulama Besar KH. Abdullaah Syafi'ie Telah Tiada";30 Pikiran Rakyat memberi judul: "KH. Abdullah

26 Lihat Koran Harian Berita Buana, 4 Sepetember 1985.

${ }^{27}$ Berita Buana, 6 Sepetember 1985.

28 Koran Harian Sinar Harapan, Selasa 3 Sepetember 1985.

${ }^{29}$ Koran Harian Pos Kota, Rabu 4 Sepetember 1985.

30 Koran Harian Suara Karya, Rabu 4 Sepetember 1985.
Syafi'ie Tutup Usia"; Kompas member judul: "Ulama Besar KH. Abdullah Syafi'ie Telah Tiada". ${ }^{31}$ Pelita mengambil judul: "KH. Abdullah Syafi'ie Berpulang ke Rahmatullah", 32 dan Widuarta Berita Nusantara yang berjudul "Ulama Besar KH. Abdullah Syafi'ie". 33

\section{Karya, Keilmuan, dan Warisan Kelembagaan}

1. Karya Akademik Keagamaan

Karya KH. Abdullah Syafi'ie mencakup kelembagaan, karya tulis, dan ceramah-ceramah yang direkam dalam ratuskaset. N Karya tulis yang berhasil dilacak peninggalah Abdullah Syafi'ie sebanyak sepuluh buah karya, di samping karya terjemahannya. Karya-karya tertulis tersebut adalah sebagai berikut ini: ${ }^{34}$

a. al-Muassasāt Al-Syāfi'iyah al-Ta'limiyah. Karya ini menjelaskan tentang latar belakang Abdullah Syafi'ie mendirikan pendidikan madrasahnya, serta menggambarkan pula tentang materi pendidikan/pelajaran.

b. Bir al-Wālidaini. Karya ini membicarakan bagaimana kondisi seorang ibu yang sedang mengandung dan setelah melahirkan; dan bagaimana pemberian nama kepada si anak; proses memelihara anak dan

\footnotetext{
${ }^{31}$ Koran Harian Kompas, Rabu 4 Sepetember 1985.

32 Koran Harian Pelita, Rabu 4 Sepetember 1985.

${ }^{33}$ Warta Berita Antara, 3 Sepetember 1985.

${ }^{34}$ Hasbi Indra, Pesantren dan Transformasi Sosial, ......hal. 133-135.
} 
Zubair Ahmad : K.H. Abdullah Syafi'ie ... 331

mengisi jiwanya serta ke arah mana anak dididik. Perlunya sejak dini menanamkan jiwa agama dan pengamalan agama, menceritakan perlunya seorang anak berbakti kepada orang tua serta keberuntungan yang diperoleh seseorang apabila berbakti atau berakhlak kepada kedua orang tua.

c. Berkenalan

dengan

Perguruan Al-Syafi'iyah.

Karya ini menggambarkan tentang latar belakang serta tujuan, kurikulum dan lainnya yang berkaitan dengan pendirian pesantren putra-putri, pesantren khusus yatim dan pesantren tradisional.

d. Penduduk Dunia Hanya Ada Tiga Golongan. Dalam karya ini Abdullah Syafi'ie menyoroti manusia dalam tiga kelompok, yaitu pertama kelompok mukmin, kedua kelompok kafir, dan ketiga kelompok munafiq. Manusia kelompok pertama adalah manusia yang meyakini Allah serta mengikuti perintahnya serta menjauhi larangannya. Manusia kelompok kedua adalah manusia yang tidak percaya kepada Allah serta senantiasa melanggar perintah-Nya. Manusia kelompok ketiga adalah manusia yang berada di tengah keraguan, sehingga apa yang terucapkan sangat berbeda dengan apa yang ada di dalam hatinya. Dua bentuk manusia tersebut yaitu manusia yang kafir dan munafiq senantiasa mereka dalam kerugian terutama di akhirat.

e. Mu'jizat Saiyidunā

Muhammad, karya ini berbicara tentang mu'jizat Nabi Muhammad, juga mu'jizat nabi-nabi lainnya seperti Nabi Adam, Ibrahim, Musa, Isa dan lainnya. Nabi Muhammad dalam pandangannya mempunyai kelebihan dibandingkan dengan nabi-nabi lainnya. Misalnya Muhammad adalah cahaya, alam semesta ini ada karena ada cahaya Nabi Muhammad. Mu'jizat nabinabi lainnya juga dipunyai oleh Nabi Muhammad.

f. Al-Dīnu wa al-Masjid. Karya ini membahas tentang hubungan yang erat antara agama dan tempat ibadah (masjid). Pentingnya membangun masjid bagi umat Islam. Orang yang ikut membangun dan memakmurkannya akan mendapat keutamaan dan pahala yang besar.

g. Madārij al-Fiqhi. Abdullah Syafi'ie membahas di dalam kitab ini tentang pengertian agama, pengertian Islam, pengertian iman dan rukunrukunnya, juga berbicara tentang najis dalam konteks shalat, juga masalah pelaksanaan shalat, tentang qunut dan lainnya.

h. Hidāyah al-Awwam. Karya ini membahas tentang sifatsifat Allah yang wajib dan mustahil. Kemudian ia membahas pula masalah iman kepada para malaikat, kitab-kitab Allah, juga iman 
kepada nabi-nabi Allah dengan sifat-sifatnya seperti fathanah dan lainnya.

i. Al-Ta'limm al-Dīn. Karya ini membicarakan ajaran tentang siapa pencipta manusia, apa agamanya, siapa imannya, kiblatnya yang luas ini, juga membahas tentang rukun Islam dan rukun iman.

j. Al-Mahfuzhāt (sebanyak III jilid). Karya ini berisi sejumlah materi hadis utama yang singkat, seperti hadis tentang keutamaan iman, tentang keutamaan membaca al-Qur'an, keutamaan orang yang menuntut ilmu serta manfaat orang berilmu dan sebagainya.

Karya tulis Abdullah Syafi'ie tersebut semuanya di bidang ilmu agama Islam. Karya tulisnya ada yang berkaitan denganbidang pendidikan Islam seperti dalam tulisan yang berjudul alMuassasāt Al-Syāfi'iyah alTa'limiyah, Berkenalan dengan Perguruan Al-Syafi'iyah dan lainnya. Karya tulisnya yang berkaitan dengan bidang ilmu tauhid terlihat dalam tulisannya yang berjudul Al-Ta'lìm al-Dìn. Karya tulis yang berkaitan dengan bidang hadits terdapat dalam tulisannya yang berjudul Al-Mahfuzhāt. Dari karya-karya itu tampaknya minat keilmuan Abdullah Syafi'ie di bidang keilmuan agama Islam cukup bervariasi.

Adapun karya dalam bentuk rekaman ceramah dalam kaset-kasetnya jumlahnya ratusan. Jumlah tersebut memang sangat memungkinkan karena hampir semua ceramahnya direlai melalui radio as-Syafi'iyah dan ada rekamannya. Bahkan, sampai sekarang sebagian dari kasetkaset tersebut masih sering diputar ulang di RAS FM. Adapun materi dan kadungannya berisi tentang berbagai macam bidang ilmu agama. Penulis tidak sempat memutar kaset-kaset tersebut karena kendala waktu dan teknis, namun sebagian di antaranya sudah pernah ditranskrip oleh Hasbi Indra. ${ }^{35}$ Menurutnya, materi keilmuan yang dibahas Abdullah Syafi'ie di dalam kaset-kasetnya itu sangat berragam. Materi yang dibicarakan berkisar masalahmasalah yang berkaitan dengan proses penciptaan manusia dan pada saat tiba ajalnya; masalah yang berkaitan dengan masalah keimanan dan keislaman; masalah yang berkaitan dengan pentingnya shalat dan pengampunan dosa; masalah yang berkaitan dengan kemuliaan kitab suci al-Qur'an; masalah pentingnya ilmu pengetahuan dan teknologi serta masalah-masalah lainnya. Masalah-masalah yang dibicarakannya umumnya masalah aktual dalam kehidupan masyarakat Jakarta.

\section{Kiprah Kelembagaan}

Dalam usianya yang masih muda, Abdullah Syafi'ie sudah

\footnotetext{
${ }^{35}$ Hasbi Indra, Pesantren dan Tranformasi Sosial, h. 135-140.
} 
mulai muncul ide-ide cemerlangnya. Ketika itu, Abdullah Syafi'ie membayangkan sebuah halaqah di rumahnya sebagai tempat diskusi. Cita-cita itu kemudian disampaikan kepada ayahnya dan lokasi yang dipilih adalah kandang sapi yang ada di belakang rumahnya di Bali Matraman. Ayahnya pun setuju dengan keinginan Abdullah, maka berubahlah kandang sapi menjadi tempat pengajian.

Setelah halaqahnya mulai berjalan, Abdullah Syafi' ie kembali punya keinginan untuk melengkapinya dengan membangun masjid. Abdullah Syafi'ie ingin segera memiliki masjid sehingga ingin membeli tanah dan telah menentukan lokasi. Sayangnya, uang dimilikinya tidak cukup untuk membeli tanah. Kemudian, Abdullah Syafi'ie mendekati istri dan ibudanya untuk meminta dukungannya membangun masjid. Akhirnya, kedua wanita hebat itu bersedia membantu dengan menyerahkan kalung emas permata untuk djual dan membeli tanah wakaf untuk masjid.

Pada usia 23 tahun, Abdullah Syafi'ie mulai merancang pembangunan Masjid Al-Barkah di kampung Bali Matraman. Masjid ini terdiri atas usaha dan pengorbanan beliau, orang tua, dan istrinya. Ketika itu, masjid-masjid yang ada di wilayah Jakarta tidak diberi nama khusus dan biasanya dikenal berdasarkan kampung tempatnya berdiri, seperti Masjid Manggarai, Masjid Kebon Jeruk, Masjid Matraman, dan lain sebagainya. Berdirinya Masjdi AlBarkah merupakan pembaruan bagi penamaan masjid-masjid yang ada di Jakarta pada umumnya. ${ }^{36}$ Dari masjid ini, Abdulah Syafi'ie lebih menekuni pembinanaan masyarakat ummat, mengajak mereka ke jalan Alah. Walaupun telah memiliki madrasah dan menjadi pembina Masjid Al-Barkah, Abdullah Syafi'ie tetap saja gigih menuntut ilmu kepada guru-guru sampai ke Bogor, Habib Alwi bin Thohir Alhaddad.

\begin{tabular}{llr}
\multicolumn{1}{c}{ Pada } & \multicolumn{1}{c}{ tahun } & 1940-an, \\
Abdullah & \multicolumn{1}{c}{ Syafi'ie } & telah \\
membangun madrasah & tingkat \\
ibtidaiyah, dan secara & sederhana \\
mulai menampung pelajar-pelajar & yang mukim (tinggal) terutama dari \\
kalangan keluarga dekat. Antara \\
tahun 1954-1980, & beliau \\
mengembangkan & lembaga \\
pendidikannya dalam bentuk
\end{tabular}
pesantren. Institusi pesantren ini kemudian mengambil beragama bentuk, yaitu pesantren putra, pesantren putri, pesantren trandisional dan pesantren khusus anak yatim. Selain mendirikan pesantren, juga merintis pengajian bagi kaum ibu. Pada tahun 1948, Abdullah Syafi'ie telah mendatangkan guru bahasa Inggris untuk murid-murid madrasahnya. Setelah itu, beliau juga mendirikan sekolah umum (SMU) dan sekolah menengah kejuruan (SMK), pendidikan taman kanak-kanak, majelis taklim, poliklinik, hingga universitas. ${ }^{37}$

Pada tahun 1968, beliau mengembangkan sayap pembangunan pendidikan Islam di Jatiwaringin Bekasi. Pada tahun

\footnotetext{
${ }^{36}$ Tutty Alawiyah, "Mengenal Figur KH. Abdullah Syafi'ie Sebuah Catatan Lintas Sejarah", h. 3

${ }^{37}$ Hasbi Indra, Pesantren dan Transformasi Sosial (Jakarta: Penamadani, 2003), h. 113.
} 
1974-1975 membangun pesantren putra dan pesantren putri di Jatiwaringin. Pada tahun 1978, membangun pesantren khusus untuk Yatama dan Maskin. Pengembangansarana untuk pendidikan dan pesantren terus dikembangkan ke skitar Jakarta, seperti Cilangkap-Pasar Rebo, Payangan-Bekasi, Kampung Jakasampurna-Bekasi. Sebelum meninggal, beliau bercita-cita ingin punya pesantren al-Qur'an. Citacita itu diwujudkan oleh putranya KH. Abdul Rasyid yang membangun pesantren al-Qur'an di Pulo Ari-Sukabumi dari tanah wakaf seorang pengusaha restoren Lembur Kuring, H. Sukarno, mewakafkan tanahnya seluas 3,3 hektar di Jl. Sukabumi - Cianjur. Pada awalnya tanah itu adalah tempat rekreasi. Sekarang, pesantren K. H. Abdullah Syafi'ie telah menempati tanah seluar 27 hektar dengan sarana bangunan yang cukup lengkap. K. $\mathrm{H}$. Abdullah Syafi'ie telah meninggalkan 63 buah lembagan pendidikan Islam sebagai wujud cita-citanya yang mulia dalam rangka memajukan ummat Islam Indonesia. $^{38}$

Lembaga dakwah dan pendidikan yang didirikan oleh Abdullah Syafi'ie secara singkat adalah sebagai berikut:

a. Lembaga Dakwah

- Majelis Taklim AsSyafi'iyah 1928 dan

\footnotetext{
${ }^{38} \mathrm{H}$. Adi Badjuri (mantan wartawan TPI dan Pengurus Besar Mathla'ul Anwar), "Mengenal KH. Abdullah Syafi'ie dari Dekat," dalam Tutty Alawiyah AS (Ed.), $K$. H. Abdullah Syafi'ie di Mata Para Tokoh, Ulama, dan Cendekiawan Muslim, (Jakarta: Universitas Islam As-Syafi'iyah, 2010), 124.
}

meresmikan Badan

Kontak Majelis

Taklim (BKMT)

pimpinan putrinya tahun 1981.

- Masjid al-Barkah didirikan tahun 1933

- Radio AKPI AsSyafi'iyah 1967 (kini Radio AsSyafi'iah [RAS FM]).

b. Lembaga Pendidikan

- Madrasah alIslamiyah tahun 1940

- Madrasah

Tsanawiyah dan

Aliyah (Pagi Sore)

1954 dan secara

resmi berada di

bawah Yayasan

Perguruan Islam As-

Syafi'iyah.

- Madrasah

Tsanawiyah

lil

Muballighin wal

Muallimin tahun 1957.

- SD, SMP, SMA, SMK as-Syafi'iyah

- Pesantren putra dan pesantren putri 1963 (tingkat Ibtidaiyah, Tsanawiyah, dan Aliyah).

- Akademi Pendidikan Islam (AKPI) asSyafi'iyah tahun 1965.

- Pesantren

Tradisional (Salaf) tahun 1977

- Pesantren Khusus Yatim tahun 1977 


\section{- AKPI menjadi Universitas Islam As-Syafi'iyah tahun 1975.}

\section{Ide-Ide Pembaruan dalam Dakwah dan Pendidikan}

1. Dakwah

a. Pemberian Nama Masjid

Seperti telah diuraikan di muka, penamaan masjid yang selesai dibangun Abdullah Syafi'ie pada tahun 1933 dengan nama Masjid al-Barkah merupakan sesuatu yang baru bagi masyarakat Jakarta dan sekitarnya. Masjidmasjid di Betawi pada waktu itu umumnya dikenal dengan nama kampung tempatnya berada. Sebagai contoh, Masjid Kebon Jeruk, Masjid Matraman, dan masjid-masjid yang lain. Menurut keterangan Tutty Alawiyah AS dan beberapa santri seniornya, sejak selesainya Masjid Al-Barkah, masjid-masjid yang dibangun sesudah itu di Jakarta dan sekitarnya mulai menggunakan nama-nama Arab dan tidak lagi menggunakan nama kampung.

b. Dakwah Melalui Media Massa

Pemanfaatan radio sebagai media dakwah akan memberikan pengaruh yang cukup luas bagi masyarakat. Radio memang memiliki keunggulan dalam hal penyebaran informasi, tidak terkecuali informasi mengenai ajaran Islam. Beberapa keistimewaan radio antara lain sebagai berikut:

- Bersifat langsung, tanpa melalui proses yang kompleks;
- Tidak mengenal jarak dan rintangan;

- Memiliki daya tarik ynang kuat, karena di dalamnya terdapat beberapa hal menarik, seperti muski, kata-kata dan efeksuara.

- Biayanya relatif murah;

- Menjangkau-tempat-tempat terpencil;

- Tidak terhambat oleh kemampuan baca dan tulis. $^{39}$

Karena keunggulan yang dimiliki oleh radio tersebut, Abdullah Syafi'ie semakin bersemangat untuk membangun stasiun radio. Dengan radio itulah, beliau dapat menyampaikan pesanpesan agama kepada masyarakat secara luas. Untuk itu, pada tahun 1967, setelah mendirikan madrasah dan Akademi Keguruan Pendidikan Islam (AKPI), beliau bersama dengan para mahasiswa mulai mendirikan pemancar radio. Salah satu tujuan didirikannya pemancar tersebut adalah agar ummat terbentengi dari kekuatan komunis. Orang-orang komunis telah mendirikan Universitas Rakyat (UR) yang didirikan oleh Partai Komunis Indonesia (PKI) dan memiliki pengaruh yang cukup kuat kala itu. Abdullah Syafi'ie memanfaatkan media radio tersebut sebagai sarana dakwah untuk menanamkan pengetahuanpengetahuan Islam, dan menjauhkan dari laranganlarangannya seperti perilaku judi, mabuk-mabukan, dan lain sebagainya yang semuanya

\footnotetext{
${ }^{39}$ Moh Ali Azizi, Ilmu Dakwah (Jakarta: Kencana Prenada Media Group, 2009), Cet. 2. H. 404.
} 
berpotensi untuk menghancurkan keimanan ummat Islam. ${ }^{40}$

Dakwah melalui radio ini ternyata memang memberikan hasil yang sangat menggembirakan. Belum setahun berdirinya radio tersebut telah mampu menggiring puluhan ribu umat Islam untuk menghadiri peringatan Maulid Nabi Muhammad Saw di lapangan Istora Senayan Jakarta. Acara ini dipelopori oleh perguruan AsSyafi'iyah. Ini menjadi bukti bahwa keberadaan radio ini telah menyedot perhatian berbagai kalangan ummat Islam di Jakarta ketika itu.

Mendirikan radio di era 60an merupakan hal yang langka sehingga patut disebut sebagai salah satu bentuk pembaruan di bidang dakwah yang dilakukan oleh Abdullah Syafi'ie. Pemancar radio As-Syafi'iyah ini bahkan merupakan stasiun radio siaran swasta pertama di Jakarta. Ide pendirian radio ini sebetulnya datang dari putrinya Tutty Alawiyah setelah banyak bergaul dengan orang-orang LSM seperti Utomo Dananjaya (DKJ-TIM), Dawam Rahardjo (LSAP), Jimly As-Shiddieqy dari LP3ES, dll. ${ }^{41}$

Ada sejumlah alasan Abdullah Syafi'ie mendirikan pemancar radio ini, yaitu:

- Masih banyak para alim ulama yang kehidupannya jauh dari perkembangan teknologi;

\footnotetext{
${ }^{40}$ Dailami Firdaus, "Latar Belakang Pemikiran Dakwah KH. Abdullah Syafi'ie", h. 20.

${ }^{41}$ Utomo Dananjaya, "Kedekatan K. H. Abdullah Syafi'ie dengan Gubernur Ali Sadikin," dalam Tutty Alawiyah AS (Ed.), $K$. H. Abdullah Syafi'ie di Mata Para Tokoh..., h. 89.
}

- Ummat Islam kebayak adalah ummat nomor dua dalam penguasaan ilmu dan teknologi. Penguasaan ilmu dan teknologi selalu saja menjadi bulan-bulanannya orang Barat. Ummat Islam hanya menjadi konsumen dan penonton saja. Dengan adanya pemancar radio Islam ini, Abdullah Syafi'ie memberikan contoh bagaimana memanfaatkan teknologi sebagai media dalam berdakwah.

- Stasiun radio ketika itu merupakan media massa yang paling memungkinkan bagi bangsa Indonesia karena media televisi memerlukan biaya besar dalam operasionalnya. ${ }^{42}$

c. Organisasi Lembaga

Dakwah

Sejak masih dalam usia muda, Abdullah Syafi'ie mendirikan Majelis Taklim AsSyafi'iyah. Majelis taklim ini diperuntukan bagi kaum bapak dan kaum ibu. Majelis taklim ini berpusat di Masjid Al-Barkah yang dipimpin langsung oleh K.H. Abdullah Syafi'ie, terutama bagi kaum laki-laki. Dalam majelis taklim ini, diisi berbagai program seperti pengajian umum, kajian kitab kuning, pengajian khusus yang menghadirkan ulama dan habaib, serta pengajian yang dikaitkan dengan hari-hari besar keagamaan, seperti Maulid Nabi, Isra' dan Mikraj, Tahun Baru Islam, dan lain-lain yang hingga

\footnotetext{
${ }^{42}$ Dailami Firdaus, "Latar Belakang Pemikiran Dakwah KH. Abdullah Syafi'ie”, h. 20-21.
} 
saat ini masih dilestarikan. Ada yang khas dari pengajian ini, yaitu setiap kali K.H. Abdullah Syafi'ie memberi pengajian, beliau selalu meminta jama'ah untuk meneriakkan kalimat tauhid dan takbir. Takbir beliau sangat khas dan menimbulkan getaran tersendiri di dada para jama'ah. Dengan mengikuti takbir tersebut, ada di antara jama'ah tanpa sadar meneteskan air mata keharuan.

Sementara untuk kalangan ibu-ibu dan remaja putri, pengajian dipimpin oleh $\mathrm{Hj}$. Rogayah, istri K.H. Abdullah Syafi'ie. Setelah Hj. Rogayah meninggal, pengajian dipimpin oleh putrinya Prof. $\mathrm{Dr}$. $\mathrm{Hj}$. Tutty Alawiyah dan berlangsung sampai dengan saat ini. Di bawah kepemimpinan putrinya, Abdullah Syafi'ie meresmikan organisasi majelis taklim yang dikenal dengan Badan Kontak Majelis Taklim (BKMT) yang hingga saat ini telah memiliki cabang di seluruh Indonesia. Pengajian kaum ibu Majelis Taklim As-Syafi'iyah merupakan pengajian yang fenomenal dan paling besar hingga saat ini. Pengajian ini sudah dikembangkan sehingga memiliki kurikulum dan materi ajar yang terstruktur. Dulu, pengajian hanya dilakukan dengan sistem "jiping" (Betawi: mengaji dengan menguping saja) tanpa ada materi ajar yang jelas. Metode pengajian majelis taklim dengan menerapkan kurikulum saat ini sudah mulai banyak yang menirunya. ${ }^{43}$

\footnotetext{
${ }^{43}$ A. Ilyas Ismail, "Konsep Dakwah KH. Abdullah Syafi'ie: Membangun Masyarakat Islam melalui Pilar Dakwah, Pendidikan dan Sosial," dalam Tutty Alawiyah AS (Ed.) K.H. Abdullah Syafi'ie Membangun Bangsa Melalui Dakwah, Pendidikan dan Sosial
}

d. Peran Perempuan dalam

Dakwah

Pada masa itu, menurut Tutty Alawiyah, wanita di masyarakat Betawi maupun di daerah lain tidak diperkenankan masuk masjid. Jika ada pengajian, mereka ditempatkan di samping masjid atau bagian belakang yang biasanya gelap dan kumuh. Namun, setelah berdirinya Masjid AlBarkah, Abdullah Syafi'ie telah memberikan kesempatan yang sama bagi perempuan untuk memanfaatkan masjid sebagai tempat belajar dan pembinaan ummat. Istri beliau, Siti Rogayyah dimintanya untuk membuat pengajian khas perempuan atau kaum ibu. Pengajian secara rutin dilaksanakan setiap hari Sabtu pagi. Siti Rogayyah senantiasa didampingi oleh Abdullah Syafi'ie dan juga terkadang oleh orang tuanya, Muallim H. Achmad Mukhtar bin Murtaha. Terobosan pengajian bagi ibu-ibu di Masjid Al-Barkah ini merebak ke masjid lain di sekitar Jakarta. Siti Rogayyah mulai diundang untuk mengisi pengajian di mesjid lain seperti Masjid Mujahidin, Menteng Atas, dan tempat lainnya. ${ }^{44}$

Sepeninggal ibunya, Tutty Alawiyah AS terus melakukan pembinaan majelis taklim bagi kaum perempuan. Sampai akhirnya, majelis taklim yang dipimpinnya dibuatkan wadah untuk bersama-

(Jakarta: Universita As-Syafi'iyah, 2011), h. 33-35.

${ }^{44}$ Tutty Alawiyah AS, "Mengenal Figur KH. Abdullah Syafi'ie Sebuah Catatan Lintas Sejarah", dalam Tutty Alawiyah AS (Ed.), KH. Abdullah Syafi'ie Membangun Bangsa..., h. 4 
sama dengan majelis taklim yang lain untuk membina ummat secara terencana dan berkesinambungan melalui wadah Badan Kontak Majelis Talim (BKMT). Sejak Abdullah Syafi'ie mempercayakan kepada putrinya itu untuk memimpin majelis taklim dan mengetuai organisasi BKMT, peran perempuan dalam dakwah semakin kuat.

\section{Pendidikan}

a. Integrasi Keilmuan

K.H. Abdullah Syafi'ie dalam banyak kesempatan selalu mendengung-dengungkan bahwa Perguruan As-Syafi'iyah harus menghasilkan dokter-dokter yang sebelum menyuntik pasien setidaktidak diawali dengan basmalah dan sesudahnya mendoakan agar lekas sembuh, atau lahir seorang insiyur muslim sejati yang kalau membangun jembatan tidak menanam kepala kerbau sebagai tumbal - hal itu bertentangan akidah Islam - tetapi dimulai dengan basmalah dan memohon kepada Allah agar kuat dan bermanfaat bagi manusia. ${ }^{45}$ Ungkapan tersebut mengisyarakat adanya keinginan yang kuat agar pendidikan yang selama ini mengajarkan ilmu-ilmu agama selaiknya juga mengajarkan ilmu-ilmu umum. Dengan konsep integrasi keilmuan tersebut, akan mengakiri dikotomik-parsialistik yang memang tidak membawa kemajuan bagi ummat Islam sendiri.

\footnotetext{
${ }^{45}$ A. Ilyas Ismail, "Konsep Dakwah KH. Abdullah Syafi'ie,” h. 38.
}

Pemikiran integrasi keilmuan ini memang sangat kuat dikemukakan oleh K.H. Abdullah Syafi'ie, sehingga menjadi ciri khas perguruan As-Syafi'iyah, khususnya Universias Islam AsSyafi'iyah (UIA) Jakarta. Para pendiri UIA yang dimotori oleh Tutty Alawiyah AS, dibantu oleh beberapa tokoh seperti Utomo Dananjaya, Jimly As-Shiddiqie, dan lain-lain, memahami betul pemikiran K.H. Abdullah Syafi'ie tersebut dan merumuskannya secara lebih konsepsional dalam bentu visi-misi, orientasi, dan identitas program UIA. Ada tiga orietntasi UIA yang khas, yaitu: 1) integrasi ilmu dan agama, 2) kemandirian (profesional mandiri), dan 3) pemihakan kepada kaum dhu'afa. Sebagai bukti dan wujud dari integrasi ini, sejak didirikannya pada tahun 1980-an, UIA dideklarasikan sebgai "Kampus Tempat Berpadunya Ilmu dan Agama". Pada masa-masa awal, orientasi ini disosialisasikan secara luas. Bahkah, A. Ilyas Ismail mengklaim bahwa konsep ini pertama kali muncul di UIA dan kini menjadi hangat kembali setelah adanya konversi Institut Agama Islam Negeri (IAIN) menjadi Univeristas Islam Negeri (UIN) di berbagai provinsi. ${ }^{46}$

\section{b. Modernisasi Lembaga Pendidikan Pendidikan} yang dikembangkan oleh Abdullah Syafi'ie merupakan bagian dari kegiatan dakwahnya. Pendidikan adalah bagian integral dari dakwah

\footnotetext{
${ }^{46}$ A. Ilyas Ismail, "Konsep Dakwah KH. Abdullah Syafi'ie, h. 39
} 
itu sendiri. Dakwah yang bertujuan untuk menciptakan suatu masyarakat yang islami, baik individu, keluarga, maupun masyarakat, tidak bisa tidak harus memanfaatkan pendidikan sebagai medianya. Fungsi-fungsi dakwah yang begitu luas meliputi informasi dan pengenalan ajaran Islam, internalisasi, sosialisasi dan implementasi menjadi pendidikan menjadi wadah dakwah itu sendiri.

Karena itulah, Abdullah Syafi'ie membangun dan mengembangkan pendidikan Islam sebagai media dakwah di bawah payung Yayasan Perguruan AsSyafi'iyah, bukan saja pendidikan pesantren, melainkan juga madrasah, dan sekolah-sekolah umum yang berada di bawah wilayah Kementerian Pendidikan Nasional, mulai dari Taman Kanakkanak (TK) As-Syafi'iyah Jakarta hingga Universitas Islam AsSyafi' iyah Jakarta.

K.H. Abdullah Syafi'ie berbeda dengan pada umumnya ulama-ulama di zamannya dalam memandang modernisme. Beliau menerima sains modern sebagai kebutuhan yang dianggap mendesak untuk mencapai kemajuan ummat. Dalam konteks pendidikan Islam, modernisme biasanya diukur dari penerimaan terhadap sains modern atau yang di masa lalu sering disebut dengan "ilmu pengetahuan umum" sebagai bandingan dari "ilmu pengetahuan agama."

Hasbi

Indra menggambarkan bahwa di lembaga pendidikan As-Syafi'iyah, diberikan pelajaran-pelajaran ilmu agama, seperti fiqih, tauhid, akhlak, dan ilmu-ilmu alat, seperti nahwu dan sharaf. Kemudian, sejalan dengan berjalannya waktu, Pak Kiai mengizinkan pula untuk diberikan mata pelajaran umum, seperti bahasa Inggris, aljabar, ilmu ukur, dan lain-lain. ${ }^{47}$

Bahkan, Abuddin Nata menegaskan bahwa untuk masa tahun 1960-an, pemikiran ini tergolong modern mengingat masih banyak ulama Indonesia ketika itu, juga di negeri-negeri Islam lainnya, yang melarang dan menganggap mata pelajaran seperti itu sebagai produk Barat, sementara Barat adalah kafir, penjajah, dan musuh ummat Islam. Berlainan dengan pandangan yang konservatif ini, K.H. Abdullah Syafi'ie justru memandang perlu dan menjadi keharusan bagi ummat Islam agar mencapai kemajuan. Itu sebabnya, beliau mendirikan pesantren dan madrasah di bawah naungan Kementerian Agama, tetapi juga mendirikan sekolah-sekolah umum di bawah Kementerian Pendidikan Nasional. Fakta inilah yang dijadikan dasar pemerhati pendidikan Islam untuk menempatkan K.H.Abdullah Syafi'ie sebagai seorang pelopor pembaharuan pendidikan Islam di Indonesia. $^{48}$

\section{E. Penutup}

Berdasarkan uraian terdahulu, penulis dapat menarik beberapa kesimpulan sebagai berikut. Pertama, latar belakang sosial historis dan keagamaan mengalami 4 masa, yaitu masa penjajahan Belanda, penjajahan

\footnotetext{
${ }^{47}$ Hasbi Indra, Pesantren dan Transformasi Sosial..., h. 176.

${ }^{48}$ Abuddin Nata, Pembaharuan Pendidikan Islam di Indonesia, (Jakarta: Raja Grafindo Persada, 2005.), h. 169.
} 
Jepang, era Orde Lama, dan Era Orde Baru. Adapun kiprah K.H. Abdullah Syafi'ie dalam masa-masa itu cukup besar yang ditandai dengan adanya banyak warisan akademik dan lembaga dakwah/pendidikan yang ditinggalkan, termasuk keterlibatannya dalam MUI Pusat dan MUI Provinsi DKI Jakarta.

Kedua, Warisan intelektual berupa karya tulis terdiri 10 buah buku, ratusan kaset rekaman ceramah, radio siaran sebagai media dakwah Islam. Dari segi kelembagaan, Abdullah Syafi'ie telah mewariskan semua model pendidikan Islam, baik yang salaf maupun khalaf, baik pesantren/madrasah maupun sekolah umum, dan mulai dari tingkat Taman Kanak-kanak hingga universitas.

Ketiga, pemikiran K.H. Abdullah Syafi'ie dalam pengembangan dakwah berupa inisiasi penamaan masjid tidak berdasarkan nama kampung; pendirian radio siaran untuk dakwah islamiyah, pembentuk wadah organisasi majelis taklim, dan pemberian peran perempuan dalam dakwah. Adapun dari aspek pendidikan, KH. Abdullah Syafi'ie berhasil melakukan integrasi keilmuan Islam dan sains, serta melakukan modernisasi lembaga pendidikan Islam. Kedua pemikiran modern ini muncul karena pergaulan $\mathrm{K}$. $\mathrm{H}$. Abdullah Syafi'ie dengan anak-anak muda dari LSM, seperti Utomo Dananjaya dari Dewan Kesenian Jakarta Taman Ismail Marzuki (DKJTIM), AM Fatwa dari Koordinasi Dakwah Islam (KODI), Dawam Rahardjo dari LSAF, Adi Sasono dari LSP, Jimly As-Shiddieqy dari LP3ES, Amin Rais dari PPA, para KAHMI, dan putrinya sendiri Tutty Alawiyah.

\section{Daftar Pustaka:}

Azyumardi Azra, "Pengantar" dalam Rakhmad Zailani Kiki dkk. Genealogi Intelektual Ulama Betawi: Melacak Jaringan Ulama Betawi dari Awal Abad ke-19 sampai Abad ke-21, Jakarta: Jakarta Islamic Centre, 2011.

Tutty Alawiyah AS (Ed.), $K H$. Abdullah Syafi'ie di Mata Para Tokoh, Ulama, dan Cendekiawan Muslim, Jakarta: Universita As-Syafiiyah, 2010.

Tutty Alawiyah AS (Ed.), K.H. Abdullah Syafi'ie Membangun Bangsa Melalui Dakwah, Pendidikan, dan Sosial, Jakarta: Universita As-Syafiiyah, 2010.

Abdul Aziz, Islam dan Masyarakat Betawi, Jakarta: Logos, 2002.

Uka Tjandrasasmita, Arkeologi Islam Nusantara, Jakarta: KPG, 2009.

Rakhmad Zailani Kiki dkk. Genealogi Intelektual Ulama Betawi: Melacak Jaringan Ulama Betawi dari Awal Abad ke-19 sampai Abad ke-21, Jakarta: Jakarta Islamic Centre, 2011.

Ridwan Saidi dan Alwi Sahab pada Seminar Genealogi Intelektual Ulama Betawi, 27 Maret 2007 di JIC.

Hasbi Indra, Pesantren dan Transformasi Sosial: Studi Atas Pemikiran KH. Abdullah Syafi'ie dalam Bidang Pendidikan islam, Jakarta: Pena Madani, 2003.

Tutty Alawiyah AS, "Mengenal Figur KH. Abdullah Syafi'ie Sebuah Catatan Lintas Sejarah" dalam Tutty Alawiyah AS (ed.), Satu Abad KH. Abdullah Syafi'ie (1910-2010): Kepemimpinan dan Keteladanan KH. Abdullah Syafi'ie, Jakarta: Universitas Islam As-Syafi'iyah, 2010. 
Ahmad Fadhli HS, Ulama Betawi: Studi tentang Jaringan Ulama Betawi dan Kontribusinya terhadap Perkembangan Islam Abad ke-19 dan 20,Jakarta: Manhalun Nasyi-in Press, 2011.

Dailami Firdaus, "Latar Belakang Pemikiran Dakwah KH. Abdullah Syafi'ie", dalam Tutty Alawiyah AS (Ed.), $K H$. Abdullah Syafi'ie Membangun Bangsa Melalui Dakwah, Pendidikan, dan Sosial, Jakarta: Universita As-Syafiiyah, 2010.

Koran Harian Berita Buana, 4 Sepetember 1985.

Berita Buana, 6 Sepetember 1985.

Koran Harian Sinar Harapan, Selasa 3 Sepetember 1985.

Koran Harian Pos Kota, Rabu 4 Sepetember 1985.

Koran Harian Suara Karya, Rabu 4 Sepetember 1985.

Koran Harian Kompas, Rabu 4 Sepetember 1985.

Koran Harian Pelita, Rabu 4 Sepetember 1985.

Warta Berita Antara, 3 Sepetember 1985.

Moh Ali Azizi, Ilmu Dakwah,Jakarta: Kencana Prenada Media Group, 2009), Cet. 2.

A. Ilyas Ismail, "Konsep Dakwah KH. Abdullah Syafi'ie: Membangun Masyarakat Islam melalui Pilar Dakwah, Pendidikan dan Sosial," dalam Tutty Alawiyah AS (Ed.) K.H. Abdullah Syafi'ie Membangun Bangsa Melalui Dakwah, Pendidikan dan Sosial,Jakarta: Universita AsSyafi'iyah, 2011.

Abuddin Nata, Pembaharuan Pendidikan Islam di Indonesia, Jakarta: Raja Grafindo Persada, 2005. 
